\title{
THE ROLE OF GASTRIC LOCALIZATION AND THE GASTRITIS SCORE OF HELICOBACTER PYLORI IN THE DEVELOPMENT OF EROSIVE ESOPHAGITIS
}

\author{
EROZIV ÖZOFAJIT GELIŞIMINDE HELICOBACTER PYLORI'NIN GASTRIK \\ LOKALIZASYONUN VE GASTRIT SKORUNUN ROLÜ
}

\author{
Serkan YALAKI' ${ }^{1}$ (D), Hüseyin PULAT² (D) \\ Mersin City Training and Research Hospital, ${ }^{1}$ Department of Gastroenterology, ${ }^{2}$ Department of General Surgery, Mersin, Turkey
}

ORCID IDs of the authors: S.Y. 0000-0001-8137-0924; H.P. 0000-0003-0635-3387

Cite this article as: Yalaki S, Pulat $\mathrm{H}$. The role of gastric localization and the gastritis score of Helicobacter Pylori in the development of erosive esophagitis. J Ist Faculty Med 2020;83(3):221-6. doi: 10.26650/IUITFD.2019.0085

\begin{abstract}
Objective: The interactions between Helicobacter pylori (Hp) and gastroesophageal reflux disease (GERD) are a complex issue. The aim of this study was to investigate the correlation between $\mathrm{Hp}$ infection and the gastric localization of $\mathrm{Hp}$ and reflux esophagitis (RE) in adult patients.

Material and Method: Two hundred thirty-nine patients with RE were compared with 229 age and sex matched participants in a control group. Biopsy specimens obtained from the gastric antrum and corpus were histologically evaluated.

Results: The prevalence of $\mathrm{Hp}$ infection was significantly lower in the patients with RE than in the control group (Odds ratio 1.56, $95 \% \mathrm{Cl} 1.08-2.27 ; \mathrm{p}=0.02, \mathrm{p}<0.05)$. Hp colonization in the corpus and gastrit scores in the corpus were significantly lower in the esophagitis group ( $p=0.01, p<0.05)$, but there was no significant difference in $\mathrm{Hp}$ colonization in the antrum and gastrit scores in the antrum. It was found that $\mathrm{Hp}$ colonization and gastrit score in the corpus showed a negative correlation with esophagitis development.
\end{abstract}

Conclusion: This study demonstrated that the prevalence of $\mathrm{Hp}$ infection and corpus gastritis score were significantly lower in patients with erosive reflux esophagitis than in the control group. Furthermore, it demonstrated that $\mathrm{Hp}$ colonization and corpus gastritis score were negatively correlated with esophagitis development.

Keywords: Helicobacter pylori, Reflux esopfagitis, GERD, Corpus dominant gastritis

\section{ÖZET}

Amaç: Helicobacter pylori (Hp) enfeksiyonu ve gastroözofageal reflü hastalığı (GÖRH) dünya çapında yaygın hastalıklardır. Hp ve GÖRH arasındaki etkileşim ise karmaşık bir konudur. Bu çalışmanın amacı erişkin hastalarda Hp enfeksiyonu ve Hp'nin gastrik lokalizasyonu ile reflü özefajit arasındaki ilişkiyi araştırmaktır.

Gereç ve Yöntem: Reflü özofajit tanılı 239 hasta, 229 yaş ve cinsiyet uyumlu kontrol grubu ile karşılaştırıldı. Gastrik antrum ve korpustan elde edilen biyopsi örnekleri histolojik olarak değerlendirildi. Enflamasyon, aktivite ve Hp kolonizasyonunun ciddiyeti, 0 (hiçbiri) ile 3 (en ağır) arasında skorlandı. Enflamasyon ve aktivite skorları toplandı ve gastrit skoru olarak ifade edildi.

Bulgular: Hp enfeksiyonu prevalansı RE'li hastalarda kontrol grubuna göre anlamlı olarak düşüktü (olasılık oranı 1,56 \%95 güven aralığı 1,08-2,27; $p=0,02, p<0,05)$. Korpustaki Hp kolonizasyonu özofajit grubunda anlamlı derecede düşüktü, fakat antrumda Hp kolonizasyonunda anlamlı bir fark yoktu (sırasıyla $p=0,01, p<0,05$ ve $p=0,09, p>0,05)$. Korpustaki Hp kolonizasyonu ve gastrit skorunun özofajit gelişimi ile negatif korelasyon gösterdiği, antrum ve gastrit skorundaki Hp kolonizasyonunun özofajit ile korelasyon göstermediği bulundu.

Sonuç: Sonuç olarak, bu çalışmada Hp enfeksiyonu ve korpus gastrit skoru sıklığının, eroziv reflü özofajit hastalarında kontrol grubuna göre anlamlı derecede düşük olduğu gösterilmiştir. Ayrıca, Hp kolonizasyonu ve korpus gastrit skorunun özofajit gelişimi ile negatif korele olduğunu göstermiştir.

Anahtar Kelimeler: Helicobacter pylori, Reflü özofajit, GÖRH, Korpus dominant gastrit

Corresponding author/iletişim kurulacak yazar: serkanyalaki@hotmail.com

Submitted/Başvuru: 21.10.2019 • Accepted/Kabul: 27.02.2020 • Published Online/Online Yayın: 24.06.2020

(C) Telif Hakkı $2020 \mathrm{~J}$ Ist Faculty Med - Makale metnine jmed.istanbul.edu.tr web sayfasından ulaşılabilir.

CCopyright 2020 by J Ist Faculty Med - Available online at jmed.istanbul.edu.tr 


\section{INTRODUCTION}

Gastroesophageal reflux disease (GERD) is characterized by the presence of reflux symptoms caused by damage to the esophageal mucosa or abnormal backflow of gastric content into the esophagus. Although it is common in Western societies, in recent years, GERD has become more prevalent in Asian populations, which may be associated with numerous factors such as increased Western dietary habits, advanced age, male gender, obesity, increased gastric acid secretion and reduced Helicobacter pylori $(\mathrm{Hp}$ ) infection $(1,2)$. The acidity of reflux content (ie $\mathrm{pH}<4)$ is a very important risk factor in the development of esophageal mucosal damage (3).

$\mathrm{Hp}$ is a type of bacteria that commonly colonizes the inner surface of the stomach. Hp infection is considered an important risk factor for the development of gastric and duodenal ulcers. Hp infection has also been shown to be associated with the development of chronic active gastritis, gastric atrophy, gastric metaplasia, dysplasia and gastric malignancies (ie gastric carcinoma, gastric mucosa-associated lymphoid tissue (MALT) lymphoma). There is strong evidence that eradication is important for the treatment of Hp-related diseases (4).

Both $\mathrm{Hp}$ infection and GERD are common diseases worldwide and the relationship between the two diseases is a very complex issue. There are various pathophysiological factors in the development of GERD and $\mathrm{Hp}$ infection may be only one of them. Many studies accentuate the coexistence of $\mathrm{Hp}$ infection and GERD. The acidity of reflux content is an important factor in the pathophysiology of refux esophagitis (RE). Hp infection may increase or decrease acid secretion depending on the type of gastritis caused, so Hp infection can be a factor or protective factor contributing to the development of GERD. Gastritis and inflammation in the corpus cause hypoacidity, while antral gastritis and inflammation have the opposite effect. Hyperacidity caused by antral gastritis can be responsible for the development of duodenal ulcers and GERD, thus an improvement in pre-existing RE may occur after $\mathrm{Hp}$ elimination. Hp infection in adults usually causes corpus-associated gastritis, which may result in the development of atrophic gastritis. Atrophic gastritis may provide protection against GERD due to hypoacidity. Pangastritis is usually associated with CagA strains of $\mathrm{Hp}$, causing more severe gastric inflammation. This intense inflammation may also result in gastric atrophy. In the case of Hp-positive corpus gastritis, pangastritis and atrophic gastritis in the stomach, the expectation is that RE is exacerbated if $\mathrm{Hp}$ is eliminated (5-12).

The aim of this study was to investigate the correlation between RE and gastric localization of $\mathrm{Hp}$ and the score of gastritis caused by $\mathrm{Hp}$ infection in adult patients.

\section{MATERIALS AND METHODS}

The records of 3850 patients who underwent endoscopy between December 2017 and March 2019 in the endoscopy unit of territory hospital were retrospectively reviewed. Of the scanned group, there were 284 patients with RE. The inclusion criteria were established to include patients with biopsy specimens taken from the antrum and corpus. The exclusion criteria were determined as follows: those with upper gastrointestinal malignancy, gastric outlet obstruction, previous gastric surgery, hiatal hernia, and obese individuals (BMl>30). The study group was created with 239 patients with RE who met these criteria. The Los Angeles classification system was used to describe the presence and severity of GERD. RE was confirmed by endoscopy according to a 5 grade severity scale. The control group consisted of age- and sex-matched patients (226 patients) randomly selected from the non-esophagitis group who underwent endoscopy.

Ethics committee approval was received for this study from the ethics committee of our hospital.

\section{Histology}

Biopsy specimens acquired from gastric antrum and corpus were evaluated histologically. The intensity of inflammation, activity and $\mathrm{Hp}$ colonization was scored from 0 (none) to 3 (severe) according to the updated Sydney system. The gastritis score was found by adding the inflammation and activation scores of the patients (13). The presence of $\mathrm{Hp}$ in any specimen in the biopsy reports was considered as positive.

\section{Statistical analysis}

The results were analyzed with SPSS (version 22 SPSS, Chicago, Illinois USA) software. Descriptive statistics were used to report the prevalence of the distribution of age, sex and of endoscopic-pathological findings in the groups. The Student's t test was applied for parametric rates between the independent groups. The Chi-square test or Mann-Whitney $U$ test was used for the statistical analysis between the endoscopic data and pathology findings. Correlation analyses were carried out for the correlation between the results. A $p$ value of $<0.05$ was considered statistically significant.

\section{RESULTS}

There were 239 patients (138 males (57.7\%), 101 females $(43.3 \%))$ in the study group and 226 patients (128 males (56.6\%), 98 females (43.4\%)) in the control group. The mean ages in the study and control groups were 49.37 ( $\mathrm{SD} \pm 14.48$ years) and 49.09 ( $\mathrm{SD} \pm 14.85$ years) years, respectively. There was no statistically substantial distinction between two groups in terms of age $(p=0.22, p>0.05)$ and gender $(p=0.63, p>0.05)$ (Table 1). 
Table 1: Descriptive statistics of groups.

\begin{tabular}{lccc}
\hline & Study group & Control group & $p$ \\
$\mathrm{n}$ & 239 & 226 & $(\mathrm{p}=0.22, \mathrm{p}>0.05)$ \\
Age & $49.37(\mathrm{SD} \pm 14.48)$ & $49.09(\mathrm{SD} \pm 14.85)$ & \\
Gender & 138 Male $(\% 57.7)$ & 128 Male $(\% 56.6)$ & $(p=0.63, p>0.05)$ \\
& 101 Female $(\% 43.3)$ & 98 Female $(\% 43.4)$ & $(p=0.02, p<0.05)$ \\
\hline
\end{tabular}

In accordance with the Los Angeles classification, there were 113 patients (47.3\%) with grade A RE, 117 patients (49\%) with grade $B R E, 6$ patients $(2.5 \%)$ with grade C RE and 3 patients (1.3\%) with grade D RE in the RE group.

$\mathrm{Hp}$ infection was defined in 131 (54.80\%) of 239 patients with the diagnosis of RE and in 147 (65.00\%) of 226 matched subjects in the control group. The prevalence of infection was significantly lower in the patients with RE than in the control group (Odds ratio 1.56, 95\% confidence interval 1.08-2.27; $p=0.02, p<0.05$, Chi square test) (Figure 1).

According to the Sydney classification, the groups were categorized for $\mathrm{Hp}$ colonization in the corpus and antrum. In the study group, $\mathrm{Hp}$ colonization in the corpus was as follows: None 142 patients (59.4\%), mild + 54 patients (22.6\%), moderate ++33 patients (13.8\%), severe +++10 patients (4.2\%). In the control group, it was as follows: none 106 patients $(46.9 \%)$, mild +67 patients $(29.6 \%)$, moderate ++41 patients (18.1\%), severe +++12 patients $(5.3 \%)$. Hp colonization in the corpus was significantly different in the esophagitis group ( $p=0.01, p<0.05$; Mann-Whitney $U$ test). In the study group, $\mathrm{Hp}$ colonization in the antrum was as follows: None 111 patients (46.4\%), mild + 68 patients

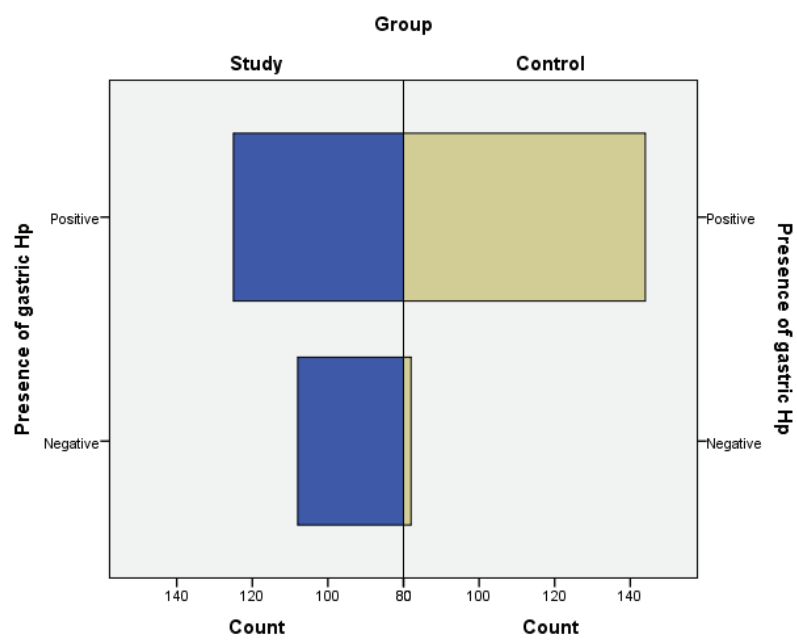

Figure 1: Presence of gastric Hp. The prevalence of infection was significantly lower in the patients with reflux esophagitis than in the control group (Odds ratio 1.56, 95\% confidence interval 1.08-2.27; $p=0.02, p<0.05$, Chi square test). (Hp: Helicobacter pylori).
(28.5\%), moderate ++45 patients $(18.8 \%)$, severe +++15 patients (6.3\%). In the control group, it was as follows: none 86 patients $(38.1 \%)$, mild +75 patients $(33.2 \%)$, moderate ++48 patients $(21.2 \%)$, severe +++17 patients $(7.5 \%)$.
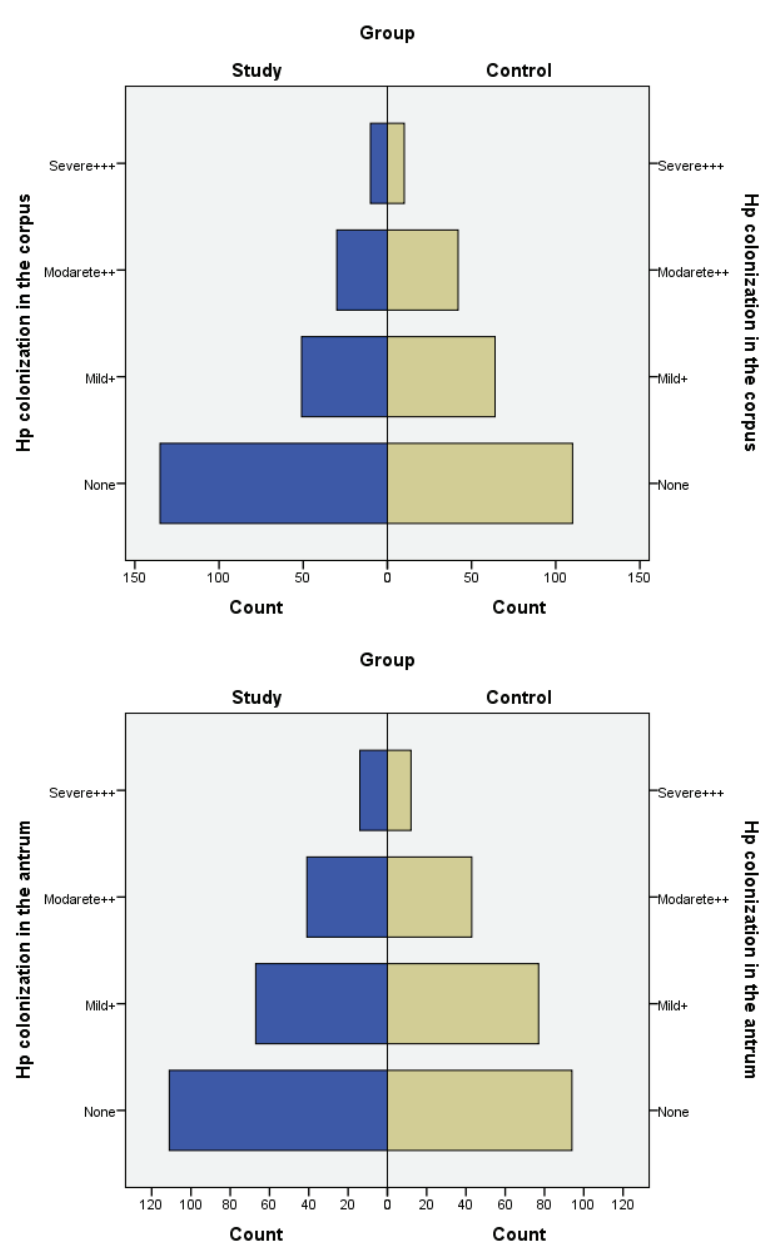

Figure 2: $\mathrm{H}$ pylori colonization in corpus and antrum. Hp colonization in the corpus was significantly different in the esophagitis group, but there was no significant difference in $\mathrm{Hp}$ colonization in the antrum $(p=0.01, p<0.05$ and $p=0.09$, $p>0.05$ respectively, Mann-Whitney $U$ test). It was found that $\mathrm{Hp}$ colonization in the corpus showed a weak negative correlation with esophagitis development, whereas $\mathrm{Hp}$ colonization in the antrum was not correlated with esophagitis development $\left(r_{s}=-0.12, p=0.01, p<0.05\right.$ and $r_{s}=-0.54 ; p=0.19$, $p>0.05$ respectively, Spearman's correlation analysis). 
There was no disparity between the groups in terms of $\mathrm{Hp}$ colonization in the antrum ( $p=0.09, p>0.05$; Mann-Whitney U test).

When the correlation between esophagitis development and gastric $\mathrm{Hp}$ localization was investigated, it was found that HP colonization in the corpus was weakly negatively correlated with esophagitis development $\left(r_{s}=-0.12, p=0.01\right.$, $p<0.05$, Spearman's correlation analysis). Whereas, it was found that $\mathrm{Hp}$ colonization in the antrum was not correlated with esophagitis development $\left(r_{s}=-0.54 ; p=0.19, p>0.05\right.$, Spearman's correlation analysis) (Figures 2).

When the groups were compared according to corpus and antrum gastritis scores, the mean corpus gastritis score of the study group was $1.94(\mathrm{SD} \pm 1.24)$; in the control group, the mean was 2.39 ( $S D \pm 1.23)$. Corpus gastritis score was significantly lower in the study group $(p=0.01, p<0.05$;
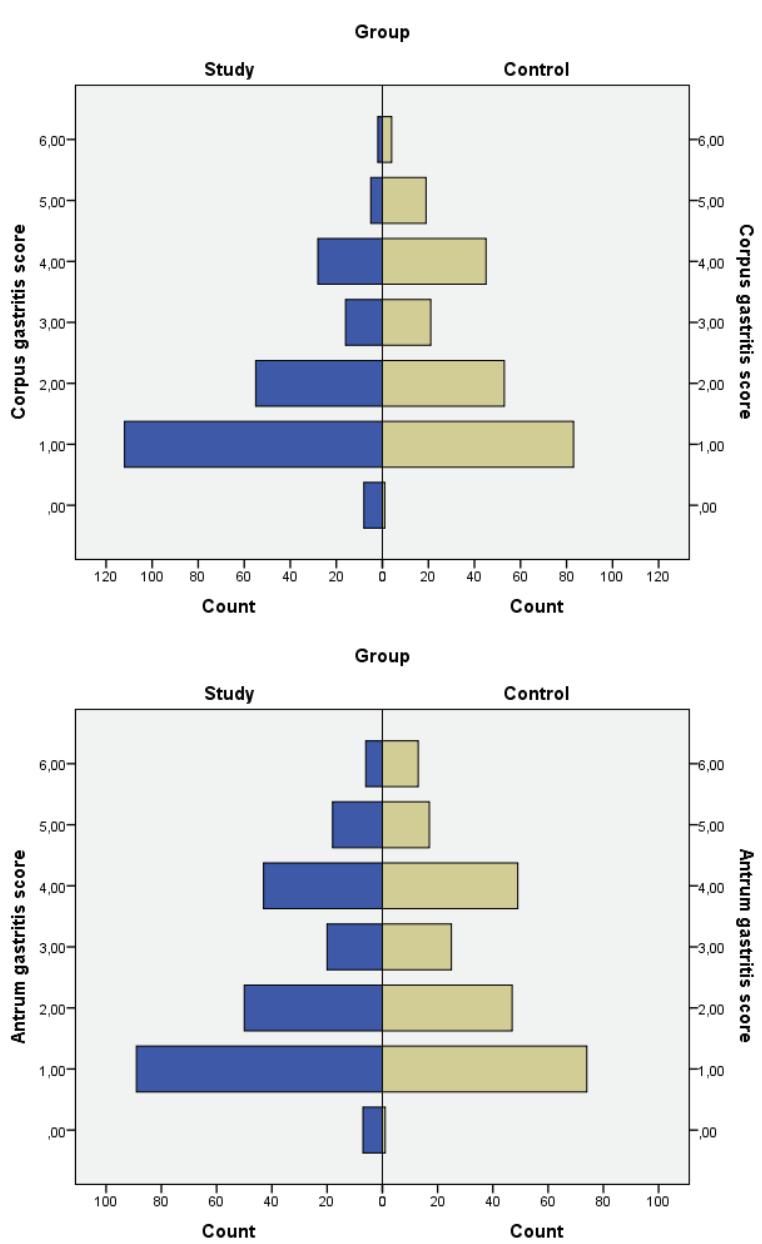

Figure 3: Corpus gastritis and antral gastritis scores in study and control groups. Corpus gastritis score was negatively correlated with esophagitis, whereas antrum gastritis score did not correlate with esophagitis $\left(r_{s}=-0.19 ; p=0.00, p<0.05\right.$ and $r_{s}=-0.86 ; p=0.63, p>0.05$ respectively, Spearman's correlation analysis).
Mann-Whitney $U$ test). Antrum gastritis scores were 2.33 $(\mathrm{SD} \pm 1.47)$ and $2.63(\mathrm{SD} \pm 1.61)$, respectively. There was no significant difference between the groups in terms of antral gastritis scores $(p=0.17, p>0.05$; Mann-Whitney $U$ test). It was found that corpus gastritis score was negatively correlated with esophagitis development $\left(r_{\mathrm{s}}=-0.19\right.$; $p=0.00, p<0.05$, Spearman's correlation analysis). Whereas, antrum gastritis score was not correlated with esophagitis development $\left(r_{s}=-0.86 ; p=0.63, p>0.05\right.$, Spearman's correlation analysis) (Figures 3 ).

\section{DISCUSSION}

Hp infection and GERD are common diseases worldwide. The nature of the relationship between $\mathrm{Hp}$ and RE has not been fully understood. In 1997, Labenz first reported the protective role of $\mathrm{Hp}$ infection for GERD (7). Afterwards, some authors highlighted the interaction between these diseases involving gastric acid secretion. The acidity of reflux content is an important factor in the pathophysiology of RE and for this reason efficacious treatments are set on suppression of gastric acid secretion (3). Hp infection may contribute to GERD through the agency of diverse mechanisms. It may have both preventive and offensive roles in the incidence and severity of GERD (5-10). Hp infection has been shown to be one of the most important reasons contributing to inflammation and atrophy of the gastric corpus and as a result it has been shown to cause gastric hyposecretion (11).

In our study, we clearly showed that the prevalence of $\mathrm{Hp}$ infection was significantly lower in the study group compared to the age and sex matched control group (Odds ratio 1.56, 95\% confidence interval 1.08-2.27; $p=0.02, p<0.05$, Chi square test). When the literature is reviewed, similarly, many studies have shown that the incidence of HP is lower in GERDs, and that $\mathrm{Hp}$ infection may have a protective effect on GERD (9-12). In a systematic review, Raghunath et al. (8) estimated the $\mathrm{Hp}$ rate in patients with and without GERD and showed a lower incidence in patients with GERD. These results suggest that the elimination of $\mathrm{Hp}$ may increase the incidence of GERD (7). However, there are also studies reporting conflicting results in the literature, and there are some publications reporting that the eradication of $\mathrm{Hp}$ has a curative effect on GERD (14-18).

The features of Hp gastritis have already been studied in GERD patients. The negative correlation between the severity of corpus gastritis activity and the severity of GERD was also confirmed by our study in accordance with the study by DeKoster et al. (19). In our study, the intensity of $\mathrm{Hp}$ colonization in the corpus and the severity of gastritis were milder in the RE group than in the control group. Hp colonization in the corpus was found to be weakly negatively correlated with esophagitis development $\left(r_{s}=-0.12\right.$; $p=0.01, p<0.05$, Spearman's correlation analysis). In addition, we found that corpus gastritis score was lower than 
the study group. There was also a negative correlation with esophagitis development $\left(r_{s}=-0.19 ; p=0.00, p<0.05\right.$, Spearman correlation analysis). The higher intensity of corpus gastritis in the control group suggests that $\mathrm{Hp}$ infection of the gastric mucosa has two possible mechanisms effective in the development and evolution of GERD: first, the exposure of esophageal mucosa to acid may be reduced and the development of erosion may be prevented by suppressing acid release in patients with reflux and severe gastritis in the corpus mucosa; secondly, continuous release of inflammatory mediator in the proximal stomach may have direct or indirect effects on the esophageal mucosa by increasing the sensitivity to acid $(10,20)$.

Hp infection in the antrum dominant gastritis type is characterized by hypergastrinemia and lower $\mathrm{pH}$. Patients with antral gastritis have a high risk of peptic ulcer or GERD due to low $\mathrm{pH}$. After the elimination of $\mathrm{Hp}$ infection, acid secretion will at least normalize in antral-dominant gastritis. The prospect is that the eradication of $\mathrm{Hp}$ in these patients should improve RE or at least not affect RE $(5,21$, 22). In our study, it was found that there was no correlation between $\mathrm{Hp}$ colonization in the antrum and esophagitis development $\left(r_{s}=-0.54 ; p=0.19, p>0.05\right.$, Spearman's correlation analysis). It was also found that the antrum gastritis score was not correlated with esophagitis development ( $r_{s}=-0.86 ; p=0.63, p>0.05$, Spearman's correlation analysis). This difference may be due to the fact that the prevalence of $\mathrm{Hp}$ infection and the type of gastritis it causes are different in Asian and Western populations. Epidemiological studies show that the prevalence of GERD is more common in Western countries than in Asian countries (20 to $40 \%, 5$ to $17 \%$, respectively). According to the previous studies based on Asian population, it is reported that the prevalence of GERD is lower in patients with $\mathrm{Hp}$ infection and the rates of GERD-related complications are also low. The reason for this is that $\mathrm{Hp}$ infection is mainly located in the corpus in East Asian patients and causes inflammation here $(5,6)$. However, in the Far East, European and North American populations, $\mathrm{Hp}$ infection generally causes antral-dominant gastritis and related complications (5).

In conclusion, this study showed that the frequency of $\mathrm{Hp}$ infection in the corpus and corpus gastritis score was significantly lower in patients with erosive reflux esophagitis than in the control group. Furthermore, it demonstrated that $\mathrm{Hp}$ colonization and corpus gastritis score were negatively correlated with esophagitis development. Therefore, Hp infection in the corpus and associated gastric hyposecretion may be important to prevent the progress of RE.

Ethics Committee Approval: This study was approved by the Ethical Committee of Mersin City Training and Research Hospital.

Informed Consent: Written consent was obtained from the participants.
Peer Review: Externally peer-reviewed.

Author Contributions: Conception/Design of Study- S.Y., H.P.; Data Acquisition- S.Y., H.P.; Data Analysis/Interpretation- S.Y., H.P.; Drafting Manuscript- S.Y., H.P.; Critical Revision of Manuscript- S.Y., H.P.; Final Approval and Accountability- S.Y., H.P.; Technical or Material Support- S.Y., H.P.; Supervision- S.Y., H.P.

Conflict of Interest: Authors declared no conflict of interest.

Financial Disclosure: Authors declared no financial support.

Etik Komite Onayı: Bu çalışma için etik komite onayı Mersin Şehir Eğitim ve Araştırma Hastanesi Etik Kurulu'ndan alınmıştır.

Bilgilendirilmiş Onam: Katılımcılardan bilgilendirilmiş onam alınmıştır.

Hakem Değerlendirmesi: Dış bağımsız.

Yazar Katkıları: Çalışma Konsepti/Tasarım- S.Y., H.P.; Veri Toplama- S.Y., H.P.; Veri Analizi/Yorumlama- S.Y., H.P.; Yazı TaslağıS.Y., H.P.; içeriğin Eleştirel Incelemesi- S.Y., H.P.; Son Onay ve Sorumluluk- S S.Y., H.P.; Malzeme ve Teknik Destek- S.Y., H.P.; Süpervizyon- S.Y., H.P.

Çıkar Çatışması: Yazarlar çıkar çatışması beyan etmemişlerdir.

Finansal Destek: Yazarlar finansal destek beyan etmemişlerdir.

\section{REFERENCES}

1. Adachi K, Notsu T, Mishiro T, Kinoshita Y. Long-term effect of Helicobacter pylori eradication on prevalence of reflux esophagitis. J Gastroenterol Hepatol 2019;34(11):1963-7. [CrossRef]

2. Kim BJ, Cheon WS, Oh HC, Kim JW, Park JD, Kim JG Prevalence and risk factor of erosive esophagitis observed in Korean National Cancer Screening Program. J Korean Med Sci 2011;26(5):642-6. [CrossRef]

3. Kinoshita Y, Adachi K, Fujishiro H. Therapeutic approaches to reflux disease, focusing on acid secretion. J Gastroenterol 2003;38(S15):13-9.

4. Malfertheiner P, Megraud F, O'Morain CA, Gisbert JP, Kuipers EJ, Axon AT, et al. European Helicobacter and Microbiota Study Group and Consensus panel. Management of Helicobacter pylori infection-the Maastricht V/Florence Consensus Report Gut 2017;66(1):6-30.

5. Yucel O. Interactions between Helicobacter pylori and gastroesophageal reflux disease. Esophagus 2019;16(1):5262. [CrossRef]

6. Mungan Z, Pınarbaşı SB. Gastroesophageal reflux disease and the relationship with Helicobacter pylori. Turk J Gastroenterol 2017;28(S1):61-7. [CrossRef]

7. Labenz J, Blum AL, Bayerdörffer E, Meining A, Stolte M, Börsch G. Curing Helicobacter pylori infection in patients with duodenal ulcer may provoke reflux esophagitis. Gastroenterology 1997;112(5):1442-7. [CrossRef]

8. Raghunath A, Hungin AP, Wooff D, Childs S. Prevalence of Helicobacter pylori in patients with gastro-oesophageal reflux disease: systematic review. BMJ 2003;326(7392):737. [CrossRef] 
9. Haruma K. Review article: influence of Helicobacter pylori on gastro-oesophageal reflux disease in Japan. Aliment Pharmacol Ther 2004;20 (S8):40-4. [CrossRef]

10. Take S, Mizuno M, Ishiki K, Nagahara Y, Yoshida T, Yokota $K$, et al. Helicobacter pylori eradication may induce de novo, but transient and mild, reflux esophagitis: Prospective endoscopic evaluation. J Gastroenterol Hepatol 2009;24(1):107-13. [CrossRef]

11. Koike T, Ohara S, Sekine H, lijima K, Abe $Y$, Kato K, et al. Helicobacter pylori infection prevents erosive reflux oesophagitis by decreasing gastric acid secretion. Gut 2001;49(3):330-4. [CrossRef]

12. Sugimoto M, Uotani $T$, Ichikawa $H$, Andoh A, Furuta T. Gastroesophageal Reflux Disease in Time Covering Eradication for All Patients Infected with Helicobacter pylori in Japan. Digestion 2016;93(1):24-31. [CrossRef]

13. Dixon MF, Genta RM, Yardley JH, Correa P. Classification and grading of gastritis. The updated Sydney System. International Workshop on the Histopathology of Gastritis, Houston 1994. Am J Surg Pathol $1996 ; 20(10): 1161-81$. [CrossRef]

14. Schwizer W, Thumshirn M, Dent J, Guldenschuh I, Menne D, Cathomas G, et al. Helicobacter pylori and symptomatic relapse of gastro-oesophageal reflux disease: a randomised controlled trial. Lancet 2001;357(9270):1738-42. [CrossRef]

15. Xue Y, Zhou LY, Lin SR, Hou XH, Li ZS, Chen MH, et al. Effect of Helicobacter pylori eradication on reflux esophagitis therapy: a multi-center randomized control study. Chin Med J (Engl) 2015;128(8):995-9. [CrossRef]
16. Fallone CA, Barkun AN, Friedman G, Mayrand S, Loo V, Beech $\mathrm{R}$, et al. Is Helicobacter pylori eradication associated with gastroesophageal reflux disease? Am J Gastroenterol 2000;95(4):914-20. [CrossRef]

17. Befrits $R$, Sjöstedt $S$, Odman B, Sörngård $H$, Lindberg G. Curing Helicobacter pylori infection in patients with duodenal ulcer does not provoke gastroesophageal reflux disease. Helicobacter 2000;5(4):202-5. [CrossRef]

18. Moschos JM, Kouklakis G, Vradelis S, Zezos P, Pitiakoudis M, Chatzopoulos D, et al. Patients with established gastroesophageal reflux disease might benefit from Helicobacter pylori eradication. Ann Gastroenterol 2014;27(4):352-6.

19. DeKoster E, Ferhat M, Deprez C, Deltenre M. H. pylori, gastric histology and gastro-oesophageal reflux disease. Gut 1995;37(S1):A36.

20. Manes G, Mosca S, Laccetti M, Lioniello M, Balzano A. Helicobacter pylori infection, pattern of gastritis, and symptoms in erosive and nonerosive gastroesophageal reflux disease. Scand J Gastroenterol 1999;34(7):658-62. [CrossRef]

21. Graham DY, Yamaoka YH. H. Pylori and cagA: relationship with gastric cancer, duodenal ulcer, and reflux esophagitis and its complications. Helicobacter 1998;3:145-51. [CrossRef]

22. lijima K, Koike T, Shimosegawa T. Reflux esophagitis triggered after Helicobacter pylori eradication: a noteworthy demerit of eradication therapy among the Japanese? Front Microbiol 2015;6:566. [CrossRef] 